\title{
S. Oppong*
}

\section{FROM RISK PERCEPTION TO ACCIDENT: AN} EMPIRICAL TEST OF THE RISK CHAIN PROCESS MODEL

UDK 656.1.08:159.9](667)

RECEIVED: $2020-01-29$

ACCEPTED: 2020-12-29

\author{
This work is licensed under a Creative \\ Commons Attribution 4.0 International License
}

\begin{abstract}
SUMMARY: The purpose of this study is to investigate the influence of comprehension of road hazards communication designs and safety climate on risk perception as well as the effect of the latter on road traffic accidents among commercial vehicle drivers in Ghana. Two hundred and twenty-six (226) commercial vehicle drivers participated in this study. Questionnaires were administered to drivers who travel outbound from Accra to nine (9) other regions of Ghana to enhance the external validity of the research findings. Path analysis, using structural equation modelling, was performed on the data obtained. Results of the SEM or path analysis revealed that all the hypothesized relationships were significant except three paths. The non-significant ones included the paths from RHCDs comprehension to risk perception and to driver decision making respectively, as well as the path from driver decision making to risk-taking behaviour. Overall, the model fitting showed that the proposed model for the study derived principally from the risk chain process model has empirical support. The implications are that risk perception influences risk-taking behaviour and decision making, whereas the latter influences risk exposure. In addition, safety climate influences risk perception, risk-taking behaviour, and road traffic accidents. Similarly, risk-taking behaviour influences risk exposure while risk exposure influences road traffic involvement. These implications were discussed in the light of the existing theory and extant empirical literature.
\end{abstract}

Key words: risk chain process model, risk perception, traffic psychology, safety psychology

\section{INTRODUCTION}

Driver error is said to account for up to $90 \%$ of all road traffic accidents (Haque, Chin, \& Lim, 2010; Medina, Lee, Wierwille, \& Hanowski, 2004; National Road Safety Commission, 2010), implying any attempt to intervene will require investigating human behaviour. It is therefore, important to ensure that there are aids on the road that improve drivers' ability to recognize hazards on the road. Consistently, it has also been found that risk perception is related to accident (eg. Oppong, 2015). One explanation that has been provided is that poor risk perception results in the driver error. This also implies that it is imperati-

*Seth Oppong, Ph.D., (oppongs@ub.ac.bw or oppon.seth@gmail. com), University of Botswana, Department of Psychology, Gaborone, Botswana. ve to identify the correlates of risk perception to control or minimize the degree of error in driver perception of danger on the road.

Risk has been defined as an assessment of the likelihood and severity of adverse effects (Oppong, 2011, 2015; US National Safety Council, 2003). Risk has also been conceptualized as the probable exposure to loss, to harm or to damage (McGregor, 2006). Several theories have been proposed to explain risk and its relationship with risk-taking behaviour and occupational accident. These theories include protection motivation theory, risk compensation/homeostasis theory, risk preference theory, situated rationality theory, habituated action theory, social action theory, and social control theory. A summary of the descriptions of the various risk-related theories is presented in Table 1. 
These theories have been criticized for failing to provide an explanation as to how risk perceptions are linked to risk-taking and workplace accident. They explained why and how risk perception influences risk-taking behaviour but fail to offer any explanation as to how risk perception results in accident. Specifically, Oppong (2015, p.30) revealed that the analyses provided by the

Table 1. Summary of descriptions of the risk theories

\section{Tablica 1. Sažeti opisi teorija rizika}

\begin{tabular}{|c|c|}
\hline Risk-related theory & Description \\
\hline Protection motivation theory & $\begin{array}{l}\text { People tend to protect themselves when they anticipate negative consequences, have the desire to } \\
\text { avoid them and feel they have the ability to take preventive measures (Sheeran, Harries \& Epton, } \\
\text { 2013). }\end{array}$ \\
\hline Risk homeostasis theory & $\begin{array}{l}\text { There is a high tendency for people to assume more risks when there is a greater sense of security. } \\
\text { People tend to regulate their level of risk-taking behaviour in accordance with the safety measures } \\
\text { available in the workplace (Wilde, 1994). }\end{array}$ \\
\hline Situated rationality theory & $\begin{array}{l}\text { High-risk behaviours are not inherently irrational but serve a purposeful function. Thus, this theory } \\
\text { focuses on the functions of the risk-taking behaviour that are not known by observers but are known } \\
\text { by the risk-taker (Cafri, Thompson, Jacobsen \& Hillhouse, 2009). }\end{array}$ \\
\hline Habituated action theory & $\begin{array}{l}\text { Repeatedly engaging in high-risk behaviour without the expected undesirable consequences will } \\
\text { decrease the perceived risk that the people associate with the behaviour. When one repeatedly } \\
\text { performs a high-risk action without the unpleasant consequence, he eventually becomes } \\
\text { desensitized to the risk (Weyman \& Kelly, 1999). }\end{array}$ \\
\hline $\begin{array}{l}\text { Social action and social } \\
\text { control theories }\end{array}$ & $\begin{array}{l}\text { These theories were not originally proposed for explaining risk. However, their applications have } \\
\text { been extended to the safety literature. Social action theory holds that people are more likely to take } \\
\text { risks as a result of peer pressure or a general perception within their community that a particular } \\
\text { activity or condition is low risk (Cooper, 2003). } \\
\text { Social control theory, originally proposed to explain delinquency and deviant behaviour (Hirschi, } \\
\text { 1969) suggests in the context of safety literature that the degree of connectedness of individual to } \\
\text { their organizations promotes behaviour conformity. When the organizational norm supports safe } \\
\text { working practices, then the probability of high-risk behaviour among the organizational members } \\
\text { will be reduced by the need to conform. Social action theory uses peer group and the community } \\
\text { as the foci of control. Social control theory uses the organization as its pivot of control. }\end{array}$ \\
\hline Risk preference theory & $\begin{array}{l}\text { This theory proposes that there are certain personal characteristics which predispose individuals } \\
\text { to take on more risk (Raouf, 1998; Oppong, 2015). Miner (2002) reported that external locus of } \\
\text { control, extraversion, aggression, social maladjustment, anxiety, depression, and impulsivity are all } \\
\text { associated strongly with high risk-taking and high accident rates. }\end{array}$ \\
\hline
\end{tabular}

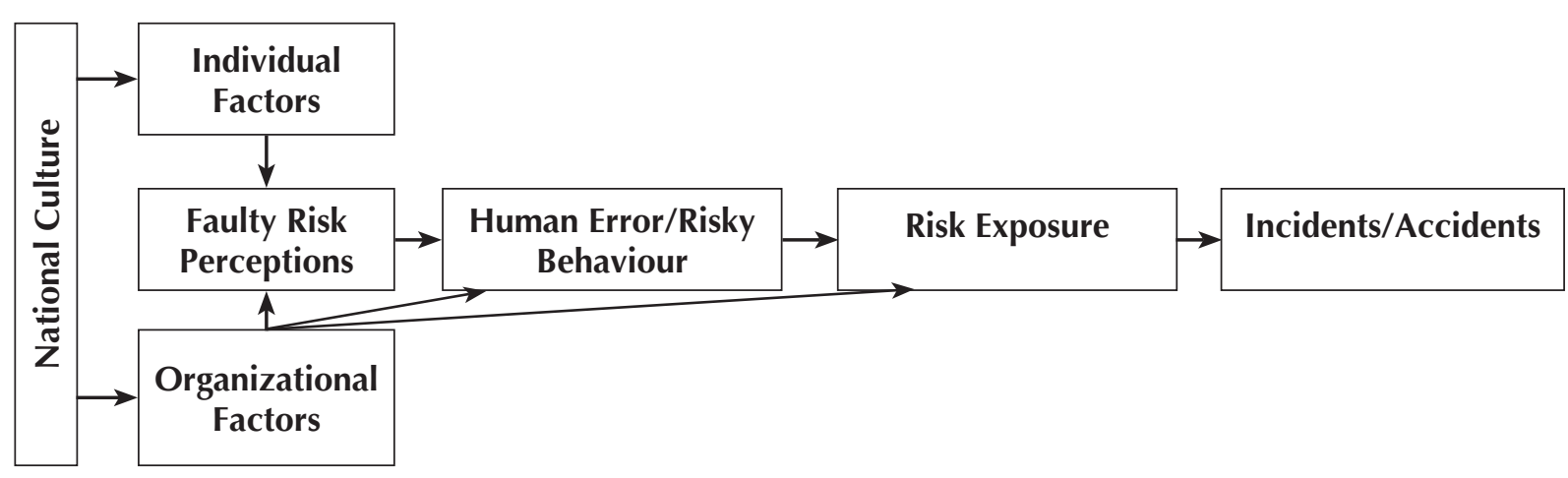

Figure 1. Risk chain process model (RCPM)

Slika 1. Procesni model lanca rizika (RCMP) 
The RCPM was developed by way of grounding its predictions with logical speculations, past findings, and existing conceptual arguments (Christensen, 2006; Colquitt \& Zapata-Phelan, 2007) and seeks to illuminate the empirical "black box" that links risk perceptions to accidents. It has also been suggested that theory testing should follow theory formulation to ensure theory refinement (Christensen, 2006; Colquitt \& Zapata-Phelan, 2007; Cortina, Aguinis, \& DeShon, 2017). This model holds that (Oppong, 2015, p.30):

...there are four keys events closely linked in a sequence such that once one event is set off it triggers the next event which sets off the other until the last event occurs. The risk chain is like a set of four dominos... that faulty risk perceptions lead to human error which manifests in risky behaviour which leads to risk exposure or exposure to hazardous conditions. The risk exposure eventually results in injuries or accidents. This does not suggest that every risk exposure will lead to accident as accidents are low-frequency events (Oppong, 2011). Faulty risk perceptions often lead to four critical errors: eyes-not-on-task(s), mind-not-ontask(s), being in the line-of -fire, and poor balance/grip.

The model suggests that individual and system/ organizational factors influence our risk perception which in turn influences our risk-taking behaviour. Further, risk-taking behaviour leads to risk exposure and an increased likelihood of accidents. In the context of this study, driver characteristics and driver group characteristics are expected to influence their risk perception on the road which will influence driver risk-taking behaviour. Driver risk-taking behaviour will then determine the level of risk exposure which will eventually result in Road Traffic Accidents RTA. Thus, this study seeks to explore the influence of safety climate and driver comprehension of road hazard communication designs as correlates of driver risk perception on one hand.

The choice of safety climate as a driver group characteristic is consistent with the social control theory of risk perception. This theory holds that risk perception is influenced by peer pressure and/or general perception with an organization (Cooper, 2003; Hirschi, 1969). Besides, numerous studies have established that safety climate does influence safety behaviour and accident (see Alvarado, Smith, Hoonakker, \& Carayon, 2005; Clarke, 2006, 2010; Hofmann, Burke, \& Zohar, 2017; Neal, \& Griffin, 2002, 2006; Neal, Griffin, \& Hart, 2000; Salas, Kozlowski, \& Chen, 2017; Zohar, 2000, 2010). These studies assessed the role of safety climate in accident causation largely a non-driver population but not among commercial vehicle drivers. On the other hand, the current study also explores the relationships among driver risk perception, driver risk-taking behaviour and involvement in RTAs.

Zohar (2010) has also called on safety climate scholars to move their research from merely addressing safety climate measurement issues to theoretical issues of establishing its antecedent variables, moderators, and mediators. In response to this call, this study attempts to determine mediators of the relationship between safety climate and accident. Though risk chain process model has guided other studies, this study was an attempt to test the entire model or 'theory'. However, this has guided other similar studies. For instance, a $\mathrm{PhD}$ candidate at the University of Amsterdam used the risk chain process model to guide her study of safety among automobile artisans in $\mathrm{Ni}$ geria (F. Afolabi, personal communication, September 13, 2016). Other studies include those by Thepaksorn, Siriwong, Neitzel, Somrongthong, and Techasrivichien (2017) and Bellini, Benvenuti, and Batistini (2017).

\section{Towards a proposed model based on RCPM}

A thorough review of the literature points towards existence of some empirical gaps. This section presents the key gaps and how the study addressed those gaps. To begin with, the extant literature seems to tell us that comprehension of hazard communications signs is relatively low in many non-Western societies and also suggests that the low comprehension of the symbols is responsible for high frequency of accidents (see Akple \& Biscoff, 2012; Makinde \& Oluwasegunfunmi, 2014; Martin, 2003; Razzak \& Hanson, 2010; Sandu, 2013). However, what appears missing in the literature is the direct empirical test of the relationship between comprehension of these symbols and risk perception. Thus, this study fills in the gap by providing a direct test of this usually presumed relationship. 
Safety climate has been studied extensively but less so among drivers in general and especially so among commercial vehicle drivers. So far the extant literature seems to suggest that safety climate influences certain safety outcomes such as safety behaviour, injuries, occupational accident, and safety performance (see Alvarando et al., 2005; Clarke, 2010; Hofmann et al., 2017; Neal et al., 2000; Zohar, 2010). Thus, empirical evidence exists so far to support the idea that a significant association exists between safety climate and safety behaviour or risk-taking behaviour. Inferring from available theoretical arguments, it is possible also to intimate that safety climate may influence risk perception. However, gaps still exist in the literature regarding the relationship between safety climate and risk perception. For instance, there is no direct empirical investigation of the relationship between safety climate and risk perception on one hand and between safety climate and risk perception among commercial vehicle drivers (see Salas et al., 2017). Thus, this study contributes to the literature by directly exploring this unexamined relationship.

Though a lot of studies has been conducted on decision-making, these studies tend to focus on decision-making styles rather than the accuracy of the decisions (see Bazire, Tijus, Brézillon, \& de Lavalette., 2006; Chen et al., 2015; Diamant, 2000). Again, a direct test of the relationship between risk perception and decision accuracy is rarely performed. Similarly, researchers rarely directly test the relationship between comprehension of road signs and decision-making. As a result, this study provides a direct of both relationships.

Generally, risk exposure is measured as some form of distances travelled. Extant approach to measuring risk exposure requires the availability of objective data and is at group or aggregate level. However, Elvik (2014), Hakkert and Braimaister (2002) and Wolfe (1982) suggest that individual differences do exist in the magnitude of risk to which people are exposed. This implies that such aggregate data may be misleading. Interestingly, there seems to be little or no di- rect research attention paid to the relationship between driver decision-making and risk exposure. Again, fewer studies found have directly analyzed the association between risk-taking behaviour and risk exposure. We know that risk exposure is often measured at the aggregate level or group level (see Hakkert \& Braimaister, 2002). However, what we do not know is whether perceived risk exposure measured at the individual level would be related to risk-taking behaviour. As a result, the researcher measured perceived risk exposure and investigated its relationship with risk-taking behaviour. This study also directly explored the nature and magnitude of relationship that may exist between accuracy of driver decisions and degree of exposure to risk.

Several studies have been carried out to examine the impact of safety climate on safety behaviour or safety performance of workers (see A/varando et al., 2005; Clarke, 2010; Hofmann et al., 2017; Neal et al., 2000; Zohar, 2010). Again, studies on safety climate have been conducted in formal organizational settings where there is unity of command (that is each person reports to a single manager or supervisor) (eg. Neal \& Griffin, 2006). Unlike the formal settings, in the informal context of commercial vehicle drivers in Ghana, there is no unity of command as the vehicle owner (the employer), station managers, and union leaders all represent different form of leadership to which the driver is accountable in varying degrees. Thus, this tripartite leadership influences the work of the driver. In sum, what is not known is whether perceptions of safety climate in such a context would have similar influence on driver risk-taking behaviour. In this study, attempt has been made to assess driver risk-taking behaviour rather than safety behaviour. Thus, this study contributes to the filling in of the empirical gap by way of measuring safety climate among commercial vehicle drivers in the informal sector and their risk-taking behaviour to explore the relationship between the two. Based on the extant literature in this research domain in general and the risk chain process model, the following proposed model guided the study (see Figure 2). 


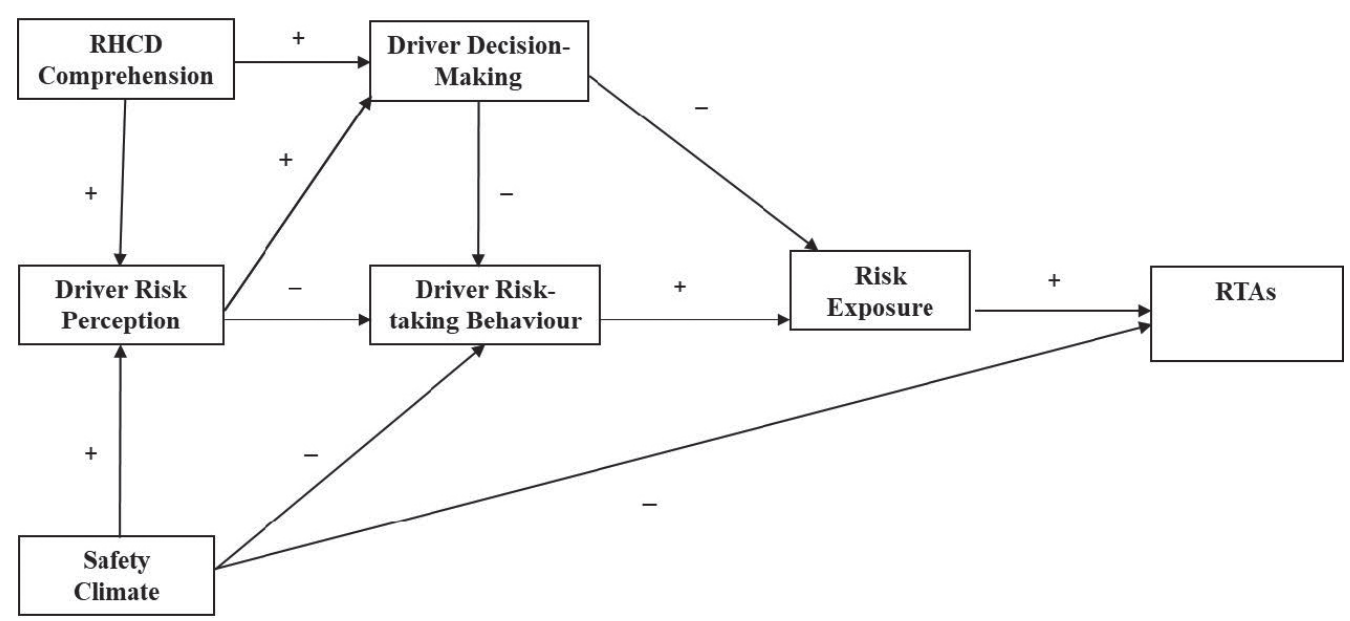

Note: RHCD = Road Hazard Communication Designs; RTA = Road Traffic Accidents

Figure 2. Hypothesized relationships among study variables based on RCPM and empirical studies Slika 2. Hipotetski odnosi između varijabli temeljeno na RCMP i empirijskim studijama

The proposed model suggests that comprehension of road hazard communication and safety climate will influence driver risk perception. Safety climate has been defined as the perceptions of policies, procedures, and practices relating to workplace safety (Neal \& Griffin, 2006). Risk perception is expected to also influence driver decision-making and risk-taking behaviour. However, safety climate is also predicted to influence risktaking behaviour and road traffic accident while RHCD comprehension is also projected to influence driver decision-making.

It is also proposed that risk-taking behaviour will predict risk exposure which will in turn result in road traffic accident. Traffic risk exposure has been defined as "simply being in a situation which has some risk of involvement in a road traffic accident" (Wolfe, 1982, p.337). More specifically, increased frequency of "being in a situation which has some risk of involvement in a road traffic accident" is more likely to be associated with higher frequency of involvement in road traffic accident.

The goal of this study is to test the general hypotheses resulting from the proposed model derived from the risk chain process model. The main objective is to assess the mechanism linking driver risk perception to road traffic accidents among commercial drivers in urban Ghana. The current study sought specifically to investigate the relationships among safety climate, RHCDs com- prehension, risk perception and RTAs. In addition, it was proposed that the relationship between safety climate and road traffic accident would be mediated by (a) risk-taking behaviour and (b) risk exposure. Again, it was also proposed that the relationship between risk perception and road traffic accident will be mediated by (a) risk-taking behaviour and (b) risk exposure.

\section{THE PRESENT STUDY}

The participants were selected from four major bus terminals or 'lorry station' in the Accra Metropolis, Greater Accra Region. The inclusion criterion for a major bus terminal is that it should be a lorry station where several commercial vehicle drivers plying different regional intercity routes operate. The purpose is to facilitate generalization of the findings to other commercial vehicle drivers in Ghana. Thus, the accessible population for this study was the commercial vehicle drivers in the Accra Metropolis whereas the commercial vehicle drivers in Ghana in general constituted the target population (see Ary, Jacobs, \& Razavieh, 2002). Specifically, the participants were selected at the following bus terminals: (i) Tudu (located at the Central Business District of Accra Metropolis), (ii) Kaneshie, (iii) Circle and (iv) Madina.

Two hundred and twenty-six (226) participants were sampled from the four research sites. These research sites were purposively selected in order 
that the participants selected would have experience of operating on inter-regional routes to and from the Accra Metropolis. Thus, drivers who travel outbound from Accra to the nine (9) other regions of Ghana were recruited to participated in the study; at the time of the data collection, there were 10 administrative regions in Ghana as opposed to the current 16 regions. Most of the participants were 40 years and above (39.7\%), had Junior High School or middle School as their highest level of education $(61.6 \%)$, identified themselves as Christians (92\%), drove minibuses $(62.7 \%)$, and received their driver training through apprenticeship $(87.1 \%)$. In addition, on the average, they have worked as commercial vehicle drivers for nearly 15 years, most of them also reported that they obtained their driver's licence through the due process of aptitude and in-traffic driving testing $(86.8 \%)$ while most were also members of Ghana Private Road Transport Union (79.8\%).

\section{Measures}

A questionnaire was constructed to assess the study variables. The questionnaire comprised 9 measures. These include demographics, road traffic accident, comprehension of hazards communication designs (RHCDs), risk perception, risk-taking behaviour, driver decision-making, perceived risk exposure and safety climate.

Road Traffic Accident Frequency. This was measured with a 14-item scale and as the frequency with which they have been involved in road traffic accident based on 14 different types of accidents identified by Vogel and Bester (2005) in Western Cape, South Africa.

Comprehension of Hazards Communication Designs. This was measured with a 20-item scale and as the comprehension or interpretation of selected existing road signs taken from National Road Safety Commission and in the Ghana Highway Code (Ministry of Roads and Transport, 1974); each item scored as either ' 1 ' for correct response or ' 0 ' for wrong response.

Risk Perception. This was measured as the perception of the probability of the certain road situations or actions or hazards resulting in a road accident; rating scale used was such that $0=$ Will never occur, $1=$ Unlikely to occur, $2=$
May occur, and 3 = Highly probable. The items were derived from Akaateba and Amoh-Gyimah's (2013) 10-item Traffic Law Violation Questionnaire (TLVQ), the 6- item Traffic Accident Risk subscale from Nordfjærn's (2006) 10-item Traffic Risk Perception Scale. Reliability coefficient for Traffic Law Violation Questionnaire was 0.757 and that for Traffic Accident Risk sub-scale was 0.806.

Risk-taking Behaviour. This consisted of a 20item scale that measured the degree of frequency with which drivers engage in certain behaviours which constitute violations of the road traffic regulations and defensive driving; this was based on observation of in-traffic behaviour of three commercial vehicle drivers, the Traffic Law Violation Questionnaire and Traffic Accident Risk subscale. The rating sale was such that $0=$ Never, 1 = Occasionally, 2 = Frequently, and 3 = Always.

Driver Decision-Making. This was assessed as the accuracy of the driver decision-making using a 25 -item scale. High scores on the scale imply that higher accuracy of decisions made and the items were derived from 960 test bank (Addo, 2011) similar to Ghana's Driver and Vehicle Licensing Authority; each item is scored as either ' 1 ' for correct response or ' 0 ' for wrong response.

Perceived Risk Exposure. A 14-tem scale was constructed to measure how close they have come in the last 6 months to being involved in road traffic accident based on 14 different types of accidents identified by Vogel and Bester (2005) in Western Cape, South Africa; rating scale was such that $0=$ Never, $1=$ Occasionally, $2=$ Frequently, and $3=$ Always.

Safety Climate. A 12-item scale was used to measure the perceived emphasis placed on safety constructed by combining items from $\mathrm{Neal}$ and Grifin's (2006) 3-item scale and additional items developed due to the web of leadership associated with commercial vehicle drivers' work in ghana (vehicle owner, union leader and station/ bus terminal management); rating scale used was such that $0=$ Not Applicable (if you have never observed such behaviour), $1=$ Completely Disagree, 2 = Disagree, $3=$ Unsure, $4=$ Agree, and 5 = Completely Agree. Neal and Griffin (2006) reported an alpha coefficient of 0.95 in 1997 (Year 2) and 0.94 in 1999 (Year 4). 


\section{RESULTS}

Data obtained were analysed using SPSS v.17 and IBM SPSS AMOS v.21. To reduce Type 1 error and to test the hypothesized relationships in the specified model simultaneously, path analysis using structural equation modelling (SEM) with IBM SPSS AMOS v.21 was performed. Additionally, the minimum sample size requirement for SEM of 200 was met (see lacobucci et al., 2007). SEM methodologists suggest that only a model that is identified or at least justified can be estimated (UIIman, 2006). The solvability of the specified model is computed by finding the difference between the number of distinct sample moments and the number of the distinct parameters. The number of distinct sample moments is given by $[K(K+1)] / 2$, where $K$ is the number variables in the specified model. The model was solvable. The following indices are recommended for reporting from the SEM analysis (Hooper, Coughlan, \&
Mullen, 2008; Hu \& Bentler, 1999) and therefore were reported in this study: (1) chi-square and its degree of freedom and $p$ value, (2) root mean square error of approximation (RMSEA), (3) nor$\mathrm{med} /$ relative chi-square statistic, (4) comparative fit index (CFI) and (5) goodness-of-fit index (GFI).

Table 3 presents the descriptive statistics such as the skewness, kurtosis, reliability coefficients and Pearson Product-Moment correlations among the study variables. The results presented in Table 3 reveal that performance on the symbols was positively correlated with accuracy of risk perception $(r=0.11, n=226, p<0.05)$, risk-taking behaviour $(r=0.13, n=226, p<0.05)$, and accuracy of driver decision making $(r=0.15, n=226, p<0.05)$. However, performance on standard symbols was not significantly related to frequency of road traffic accident $(r=0.06, n=226, p>0.05)$, perceived risk exposure $(r=0.08, n=226, p>0.05)$ and safety climate $(r=0.06, n=226, p>0.05)$.

Table 3. Skewness, kurtosis, reliability coefficients, and inter-correlations among study variables

Tablica 3. Iskrivljenost, kurtoza, koeficijenti pouzdanosti i međusobne korelacije varijabli

\begin{tabular}{|c|c|c|c|c|c|c|c|c|c|c||}
\hline $\mathbf{N} / \mathbf{S}$ & Variables & $\mathbf{S}$ & $\mathbf{K}$ & $\mathbf{1}$ & $\mathbf{2}$ & $\mathbf{3}$ & $\mathbf{4}$ & $\mathbf{5}$ & $\mathbf{6}$ & $\mathbf{7}$ \\
\hline $\mathbf{1}$ & RHCDs & 0.08 & -0.51 & $\mathbf{( . 6 8 ^ { \mathrm { a } }}$ & & & & & \\
\hline $\mathbf{2}$ & RTA & 8.47 & 93.22 & .06 & -- & & & & \\
\hline $\mathbf{3}$ & $\mathrm{RP}$ & -1.56 & 4.81 & $.11^{*}$ & -.02 & $\mathbf{( . 9 5 )}$ & & & \\
\hline $\mathbf{4}$ & RTB & 2.37 & 10.74 & $.13^{*}$ & .10 & $-.25^{* *}$ & $\mathbf{( . 8 9 )}$ & & & \\
\hline $\mathbf{5}$ & DDM & -0.81 & 0.39 & $.15^{*}$ & $-.11^{*}$ & $.27^{* *}$ & .01 & $\mathbf{( . 6 9 )}$ & & \\
\hline $\mathbf{6}$ & PRE & 2.01 & 4.43 & .08 & $.15^{*}$ & $-.21^{* *}$ & $.54^{* *}$ & $-.13^{*}$ & $\mathbf{( . 6 6 )}$ & \\
\hline $\mathbf{7}$ & SC & -0.35 & -0.60 & .06 & .11 & $.47^{* *}$ & $-.30^{* *}$ & $.12^{*}$ & $-.15^{*}$ & $(.92)$ \\
\hline
\end{tabular}

${ }^{*} \mathrm{p}<0.05 ;{ }^{* *} \mathrm{p}<0.01 ; \mathrm{n}=226$

${ }^{a}$ Numbers in parentheses along the diagonal represents the respective reliability coefficients for each of the variables.

$\mathrm{S}=$ Skewness; K = Kurtosis; RHCDs = Road Hazard Communication Designs; RTA = Road Traffic Accident; RP = Risk perception; RTB

= Risk-taking behaviour; DDM = Driver Decision Making; PRE = Perceived Risk Exposure; SC = Safety Climate. 
Again, frequency of road traffic accident (RTA) was found to correlate positively with perceived risk exposure $(r=0.15, n=226, p<0.05)$ while a significant negative correlation was recorded between RTA and driver decision making $(r=-0.11, n=226, p<0.05)$. This implies that when drivers who reported being exposed more to risks on the road also recorded high road traffic accident involvement. On the other hand, drivers who made more accurate decisions on the road also recorded lower road traffic accident involvement.

A significant positive correlation was also found between accuracy of risk perception and driver decision making $(r=0.27, n=226, p<0.01)$ and between risk perception and safety climate $(r=0.47, n=226, p<0.01)$. The implication is that drivers who had more accurate perception of risks also made better decisions and those who reported that safety was a top priority for the managers (union leaders, vehicle owners, and station managers) also reported more accurate perceptions of risks. However, a significant negative relationship was found between accuracy of risk perception and risk-taking behaviour $(r=-0.25, n=226, p<0.01)$ and perceived risk exposure $(r=-0.21, n=226, p<0.01)$. This also means that participants who reported more accurate risk perceptions were less likely to report engaging in risk-taking behaviour. Again, those who reported more accurate risk perception were also less likely to be exposed to risk on the road.

In addition, there was a significant positive relationship between risk-taking behaviour and perceived risk exposure $(r=0.54, n=226, p<0.01)$ while a significant negative correlations was observed between risk-taking behaviour and safety climate $(r=-0.30, n=226, p<0.01)$. This suggests that the more risk-taking behaviours one engaged in, the more likely that the person would be exposed to risk on the road. On the other hand, when one's managers (union leaders, vehicle owners, and station managers) perceive safety as a top priority, the less likely the person would engage in risk-taking behaviour.

A positive correlation was also observed between driver decision making and safety climate $(r=0.12, n=226, p<0.05)$ and a significant negative correlations with perceived risk exposure $(r=-0.13, n=226, p<0.05)$. These relationships imply that the more accurate were drivers' decisions, the less likely drivers would be exposed to risk and the more likely that the driver's managers would consider safety to be a priority. Another important relationship was observed between safety climate and perceived risk exposure $(r=-0.15, n=226, p<0.05)$. This showed that the more likely the driver's managers perceive safety to a priority, the less likely that the drivers would be exposed to risk on the road.

\section{Path Analysis and Test of Hypotheses}

The maximum likelihood method of IBM SPSS Analysis of Moment Structures (AMOS) version 21.0 Structural Equation Modelling programme was used to test whether pattern of hypothesized inter-relationships among the study variables fit the empirical data. Bootstrapping technique was used to test the significance of the direct and indirect paths in the model. Figure 3 presents the standardized coefficients (together with their significance level) for the path model displaying the relationships among the study variables specified in the proposed model. 


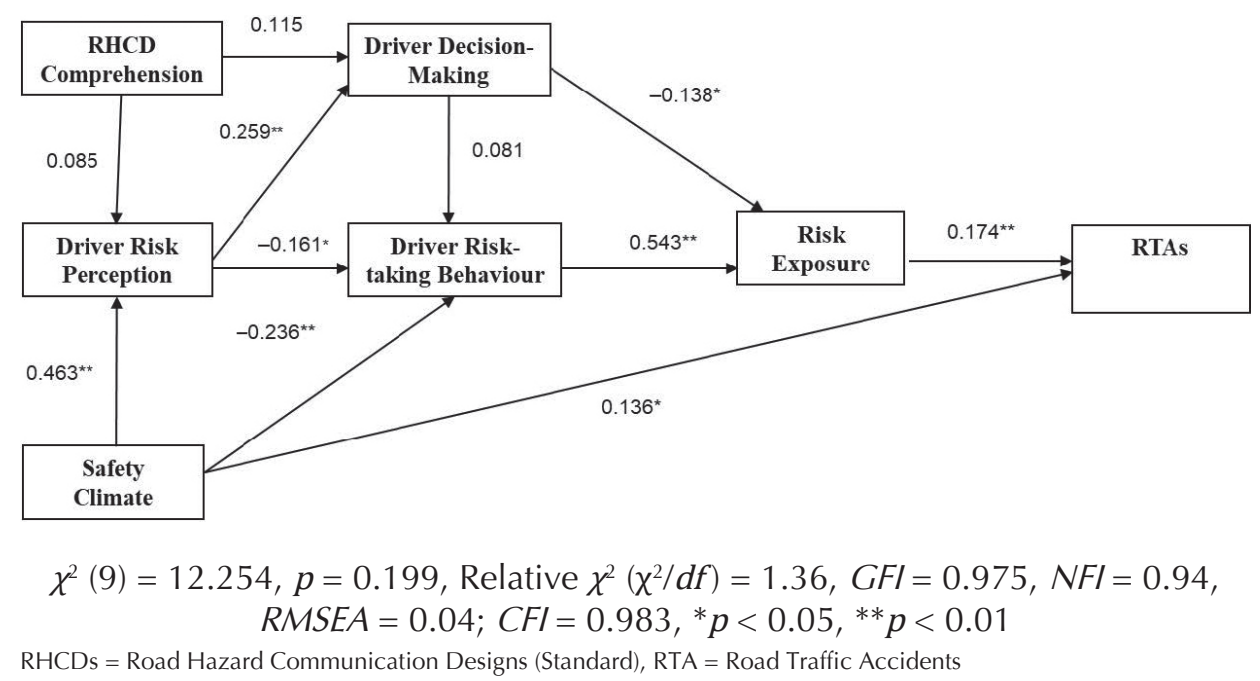

Figure 3. Path analysis showing relationships among the study variables Slika 3. Analiza staze s prikazom odnosa među varijablama

The model had good fit indices $\left[\chi^{2}(9)=\right.$ 12.254, $p=0.199$, Relative $\chi^{2}\left(\chi^{2} / d f\right)=1.36, C F I$ $=0.98, G F I=0.975, N F I=0.94, R M S E A=0.04]$ indicating the data fits the specified model. The results further show that there are eight (8) significant paths and three (3) non-significant paths. Results showed a non-significant relationship between RHCDs comprehension and risk perception $(\beta=0.085, p>0.05)$ on one hand, and a non-significant relationship between the former with driver decision $(\beta=0.115, p>0.05)$. Similarly, there was no significant negative correlation between driver decision-making and risktaking behaviour ( $\beta=0.081, p>0.05$ ).

There was, however, a significant positive relationship between risk perception and accuracy of driver decision making ( $\beta=0.259, p<0.01$ ), implying that accurate risk perceptions result in accurate decision by the drivers. Moreover, a significant negative relationship was found between accuracy of driver decision making and perceived risk exposure $(\beta=-0.138, p<0.05)$. The implication is that when drivers make more accurate decisions, they are less likely to be exposed to risk on the road.

The model also reveals that there was a positive association between risk-taking behaviour and risk exposure $(\beta=0.543, p<0.01)$. Thus, engaging in more risk-taking behaviours results in high risk exposure. Results of the analysis also showed that there was a significant positive relationship between risk exposure and road traffic accident $(\beta=0.543, p<0.01)$. Thus, when one is exposed to high risk, it increases the chance that one would also be involved in an accident.

In mediation testing by means of path analysis using SEM, Zhao, Lynch, and Chen (2010) reported that researchers should abandon Sobel Z test and use bootstrapping to test the significance of the direct and indirect (or mediated) effects. In fact, they state that (Zhao et al., 2010, p.204): We recommend that to establish mediation the Baron and Kenny "three tests + Sobel" steps be replaced with one and only one test: bootstrap test of the indirect effect... Zhao et al. (2010, p.204) further suggested that one "may use SEM to estimate all parameters simultaneously" or employ regression or run the Preacher-Hayes script in SPSS to estimate the parameters.

Both mediated relationships and were tested following Zhao et al.'s (2010) recommended steps for mediation testing in SEM. Table 4 presents the direct and indirect (mediated) effects for the study variables. As indicated earlier, it projected that the relationship between safety climate and road traffic accident would be mediated by (a) risk-taking behaviour and (b) risk exposure. 
Table 4. Direct, indirect, and total effects with significance levels

Tablica 4. Izravni, neizravni i ukupni učinci s razinama značajnosti

\begin{tabular}{||lll|c|c|c||}
\hline \hline \multicolumn{2}{|c|}{ Paths } & Direct Effect & Indirect Effect & Total Effect \\
\hline RP & $<--$ & SC & $0.463^{* *}$ & - & $0.463^{*}$ \\
\hline RP & $<---$ & RHCDs & 0.085 & - & 0.085 \\
\hline DDM & $<---$ & RP & $0.259^{* *}$ & $0.120^{*}$ & $0.259^{* *}$ \\
\hline DDM & $<---$ & SC & - & - & $0.120^{* *}$ \\
\hline RTB & $<---$ & DDM & 0.081 & $-0.065^{*}$ & 0.081 \\
\hline RTB & $<---$ & SC & $-0.236^{* *}$ & $-0.301^{*}$ \\
\hline PRE & $<---$ & RTB & $0.543^{* *}$ & $-0.020^{*}$ & $0.543^{* *}$ \\
\hline PRE & $<---$ & RHCDs & - & $-0.180^{* *}$ & -0.02 \\
\hline PRE & $<---$ & SC & - & $-0.112^{*}$ & $-0.180^{* *}$ \\
\hline PRE & $<---$ & RP & - & $-0.031^{* *}$ & $-0.112^{*}$ \\
\hline RTA & $<---$ & SC & $0.136^{*}$ & - & 0.104 \\
\hline RTA & $<---$ & PRE & $0.174^{* *}$ & $0.094^{*}$ & $0.174^{*}$ \\
\hline RTA & $<--$ & RTB & - & $-0.019^{*}$ & $0.094^{*}$ \\
\hline RTA & $<---$ & RP & - & & $-0.019^{*}$ \\
\hline
\end{tabular}

${ }^{*} p<0.05,{ }^{* *} p<0.01$. Note: Significance level is based on a bootstrap approximation obtained by constructing two-sided bias- corrected confidence intervals.

RHCDs = Road Hazard Communication Designs; RTA = Road Traffic Accident; RP $=$ Risk perception; RTB $=$ Risk-taking behaviour; DDM $=$ Driver Decision Making; PRE = Perceived Risk Exposure; $\mathrm{SC}=$ Safety Climate

Results in Table 4 indicate that there was a significant direct effect of safety climate on road traffic accident $(\beta=0.136, p<0.05)$ while there was also a significant indirect or mediated effect of safety climate on road traffic accident $(\beta=-0.031$, $p<0.05$ ), indicating a partial mediation (in Baron and Kenny's terms) or competitive mediation (in Zhao et al's terms) by (a) risk-taking behaviour and (b) risk exposure. To ensure the certainty of this mediation, the risk perception <-- safety climate path was constrained to zero (0) and the indirect effect of safety climate on road traffic accident was still present and significant. Zhao et al. (2010) have argued that the existence of completive mediation only implies the omission of some unknown mediator that should be studied further in future research.

It was also proposed that the relationship between risk perception and road traffic accident will be mediated by (a) risk-taking behaviour and (b) risk exposure. Results indicate a significant indirect effect on risk perception on road traffic accident $(\beta=-0.019, p<0.05)$ whereas the direct effect of risk perception on road traffic accident was not significant. This is not surprising given the fact that there was no significant relationship between risk perception and road traffic accident $(r=-0.02, n=226, p>0.05)$ in the intercorrelation matrix. Indeed, Rucker, Preacher, Tormala, and Petty (2011) have recommended that researchers need not be worried and be concerned about ensuring that there is a significant direct effect of the independent variable on the outcome variable in order to establish mediation. Rucker et al. (2011) have similarly cautioned against the use of full and partial mediation; they have recommended calculating, reporting and interpreting effect sizes of the indirect of effects. Zhao et al. (2010) also made similar recommendation regarding the direct effect of the independent variable on the dependent variable. To increase confidence in this mediation, the driver decision making $\leftarrow$ risk perception path was constrained to zero (0) and the indirect effect of risk perception on road traffic accident was still present and significant. Although there may not be a direct relationship between risk perception and road traffic accident, the empirical evidence suggests that faculty risk perceptions result in risk-taking behaviour while risk-taking behaviours also result in road traffic accident. 
However, a surprising finding is that though RHCDs did not have any significant regression coefficients with the expected endogenous variables (as reported in Figure 3), they had a significant mediated/indirect effect on PRE. To examine why this was the case, a second model was fitted in which $R T B \leftarrow R H C D, P R E \leftarrow R H C D$, and RTA $\leftarrow$ RHCDs paths were also estimated. It showed that the RTB $\leftarrow$ RHCD path was significant. Thus, although RHCD comprehension may not be related to risk perception and driver decision, it directly influences risk-taking behaviour which then accounts for its significant mediated effect on perceived risk exposure. Thus, the effect of RHCD comprehension on risk exposure (though there is no direct effect of the former on risk exposure) is through risk-taking behaviour. Though the regression coefficient for the DDM $\leftarrow$ RHCDs was not significant (see Figure 3), results of the tests of effects using the bootstrap approximation showed that RHCDs comprehension has a significant direct effect on driver decisions. This can equally explain its indirect effect on risk exposure. This also implies RHCD comprehension still matters as it can affect road traffic accident through its effect on driver decisions and possibly risk-taking behaviour of the drivers.

Put another way, RHCD comprehension still matters because of its direct effect on risk-taking behaviour and its mediated effect on risk exposure (note that the mediated effect on risk exposure disappears once you estimate the RTB $\leftarrow$ RHCD path). Indeed, results reported in the intercorrelation matrix (Table 3) indicate that RHCD comprehension is correlated with risk perception $(r=0.11, n=226, p<0.05)$, risktaking behaviour $(r=0.13, n=226, p<0.05)$, and driver decision $(r=0.15, n=226, p<0.05)$.

\section{DISCUSSION}

Results showed that the model had good fit indices. Contrary to expectation, the coefficients from the path model indicated that RHCD comprehension had no relationship with risk perception and driver decision making. This finding was unexpected as the literature suggested such possible relationships may exist between RHCD comprehension with those variables (see Bazire et al., 2006; Diamant, 2000). If there is no relationship, why is the study of road signs and signals relevant? Its relevance lies in the fact that the bootstrap approximation procedure used also revealed that RHCD comprehension also has a significant, direct, positive effect on driver decisions. This finding also appears consistent with Bazire et al's (2006) and Diamant's (2000) studies. The participants in these studies reported actions they would take which made the decision outcomes behaviours, if one stretches the limit of the propositions.

What is rather counterintuitive is why there was a positive relationship between risk-taking behaviour and RHCD comprehension. It can be speculated that when drivers are familiar with the road hazard communication designs, they may become less cautious than those less familiar with the signs, given that the former may believe that 'everything is under control'. It is equally possible that past non-compliance has not resulted in any undesirable consequences due to either limited enforcement of traffic regulations and/or the rare nature of accident itself. Accident is a rare event or an event with a low probability of occurrence (Clarke, 2006); it takes several unsafe behaviours for a near miss or a close call to occur and it takes several near misses for an accident to occur (Oppong, 2011). According to the habituated action theory, when one repeatedly engages in high-risk behaviours without the expected undesirable consequences, it decreases the perceived risk that the people associate with the behaviour (Weyman \& Kelly, 1999). Further, Lancaster and Ward (2002) have reported that internal locus of control is associated with a lower degree of perceived risk than those with an external locus of control. Thus, those familiar with the route may downplay the eminence and severity of the danger/hazard being communicated through the sign, hence their high risk-taking behaviour. It also implies that locus of control, coupled with awareness of hazards communicated through the signs, can possibly result in higher risk-taking behaviours. It is equally possible that drivers who are familiar with the road hazard communication designs have the benefit of anticipating what might be ahead of them and as result take calculated risks in response to the danger being communicated. 
The results further showed that no significant negative correlation existed between driver decision-making and risk-taking behaviour. However, it was conceptualized that if decisions by drivers are more accurate, then they are less likely to engage in risk-taking behaviour. Though there was no significant direct effect on risk-taking behaviour, the path analysis results showed a positive relationship. It is expected that taking calculated risk because one knows the right thing to do may also predispose the drivers to engage in more risk-taking behaviours. Thus, future studies should measure and control for the effect of self-regulatory focus (gain versus loss avoidance orientation). This finding is important as it represents one of the first attempts to provide a direct test of the relationship between decision making and risk-taking behaviour.

Furthermore, it was found that a significant negative relationship exists between driver decision-making and risk exposure. That is, drivers who make more accurate decisions are less likely to find themselves in hazardous conditions (risk exposure). In the literature, attention has been focused on the influence of risk perception on decision (see Bazire et al., 2006; Chen et al., 2015; Diamant, 2000) but has rarely studied the relationship between decision making and risktaking behaviour. In the case of the relationship between decision-making and behaviour, it is here suggested that its understudied nature may be due to (1) variability in how decisions are defined and measured and (2) the difficulty of actually observing decisions being translated into behaviours in experiments. Besides, the significant negative relationship between driver decisions and risk exposure provides evidence of validity for use of the driver decision making questionnaire (DDMQ) in both research and applied settings.

Another significant positive association was reported between risk-taking behaviour and risk exposure, another rarely studied relationship. This current finding provides a more direct test of the relationship between risk-taking behaviour and risk exposure and is consistent with evidence that can be derived from the few studies that exist. For instance, Jun et al. (2007) found a relationship between risk exposure (measured as mileage) and speeding among older drivers. Similarly, de Winter and Dodou (2010) also found a positive relationship between behaviour (traffic violations and errors) and exposure (also measured as mileage). af Wåhlberg (2011) reported a relationship between risk exposure and road traffic accident. Thus, risk exposure appears to be directly proportional to risk-taking behaviour.

As also expected, a significant positive correlation was observed between risk exposure and road traffic accident. Here again, this finding provides another direct test of a relationship that is rarely tested. Risk exposure has traditionally been assessed in studies (1) with objective indicators and (2) at aggregate or group level. However, there are convincing arguments (see Hakkert \& Braimaister, 2002; Wolfe, 1982; Paefgen et al., 2014; af Wåhlberg, 2011; Elvik, 2014) that risk exposure would result in road traffic accident. Results of the analysis showed that risk perception has an indirect impact on road traffic accident through its impact on risk-taking behaviour and risk exposure.

Further, these findings provide empirical evidence in support of the risk chain process model. The implication is that risk chain process model has both predictive and explanatory values. It can help explain why and how risk perception is related to accident. Similarly, it helps us to understand how safety climate also affects road traffic accidents. However, a positive relationship was observed between safety climate and road traffic accident but has a positive relationship with risk perception and a negative relationship with risktaking behaviour. How is it that safety climate which improves risk perception and results in more safe behaviours (less risk-taking behaviours) but results in high frequency of road traffic accident? The explanation may lie in the interpretations given to the priority on safety exhibited by the drivers. It is likely that it is interpreted as pressure on them (drivers) to perform. Indeed, TeyeKwadjo et al. (2013) observed that pressure from vehicle owners to make sales (accounts for day) was reported by the drivers as a cause of their rush on the road and the subsequent accident. Alternatively, this competitive mediation can also be understood differently in terms of the relative impact of safety climate on both risk-taking behaviour and road traffic accident. The rate of change in risk-taking behaviour due to increases in safety climate is higher compared to the rate of 
change in road traffic accident due to increases in safety climate. Similarly, the rate of change in frequency of road traffic accident due to risk-taking behaviour is higher than the rate of change in road traffic accident due to safety climate. This implies that the net effect of safety climate on road traffic accident is desirable (it results in reduction in road traffic accident frequency). Thus, safety climate has the potential to cause far more decrease in road traffic accident frequency than any increase resulting from it. A good analogy to explain the effect of safety climate on road traffic accident is the say that one cannot make omelette without breaking the eggs; the benefits of safety climate cannot be realized without some inevitable damage. The direct effect of safety climate on road traffic is simply an inevitable collateral damage associated controlling road traffic accident through improved safety climate.

\section{Revised Model}

The revised model is presented Figure 4. Generally, the Risk Chain Process Model (RCPM) proposes that risk perceptions result in risky behaviours which in turn lead to risk exposure. Finally, risk exposure results in accident. RCPM further proposes that risk perception is determined by both individual and organizational (group) characteristics; both the individual and organizational factors also depend on national culture.
Upon testing the RCPM, this study found, indeed, poor risk perception resulted in more risk-taking behaviours which in turn led to risk exposure. This risk exposure then resulted in road traffic accidents. Similarly, this study found evidence in support of the idea that organizational factors influence risk perception as safety climate (organizational factor) affected risk perception.

However, RHCDs comprehension (which is an individual factor in the context of risk chain process model) had no impact on risk perception. Does it mean that individual factors generally do not have impact on risk perception? This is not necessarily the case. It is more likely that it is this individual factor that does not have direct influence on risk perception. It is possible that personality characteristics may have influence on risk perceptions (see Lancaster \& Ward, 2002; Zhang et al., 2011). More specifically, the extant literature suggests that more experienced drivers (in terms of years involved in driving) tend to have low comprehension of the road signs (see Bazire et al., 2006). In this study, the average number of years of experience was approximately 15 years, implying the participants had a lot of experience. The implication is that the range restriction on the data due to their experience could have affected the statistical conclusion validity (see Shaddish et al., 2002). It is equally possible that this finding reflects the reality. Though the relationship

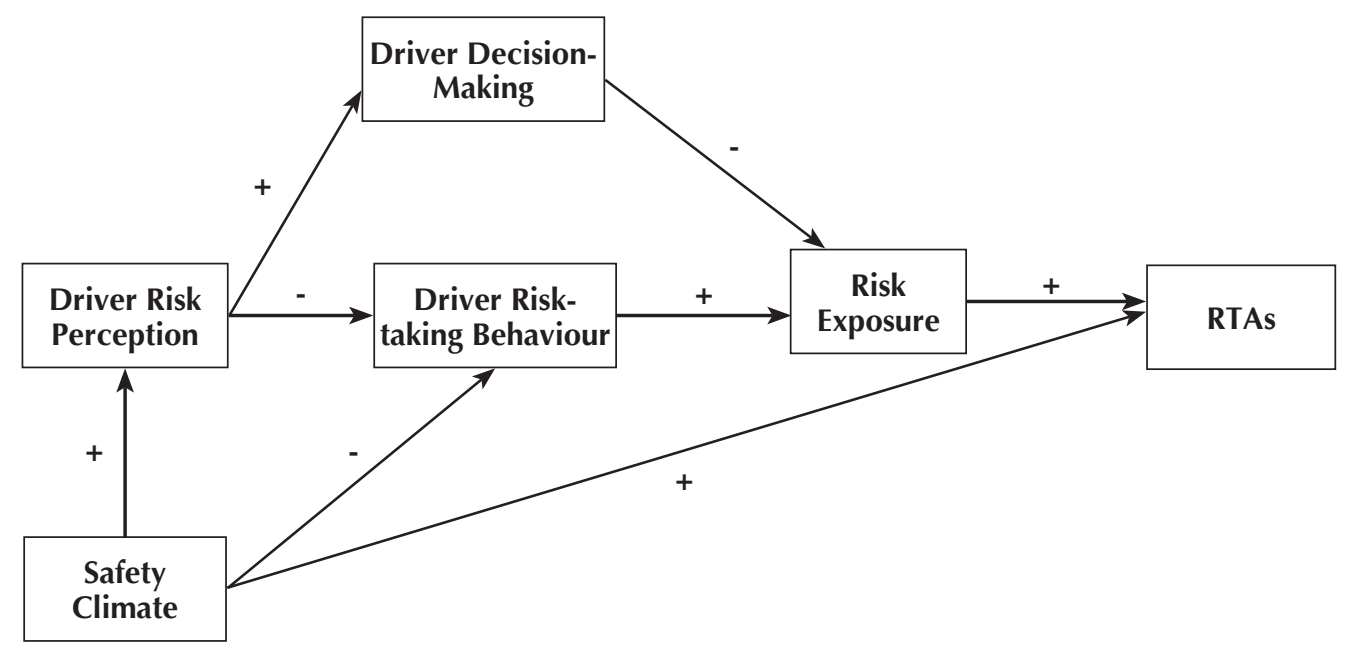

RTA = Road Traffic Accident

Figure 4. Revised model showing the observed relationships among the study variables Slika 4. Revidirani model s prikazanim odnosima među varijablama 
between organizational factor (safety climate) and risk exposure was not tested in the model fitting as proposed by RCPM, results of the intercorrelation showed that safety climate is negatively associated with risk exposure. The implication of this finding is that when emphasis is placed on safety (by the vehicle owners, union leaders, and station masters), it is more likely that the drivers will have reduced risk exposure on the road.

Notwithstanding, RHCDs comprehension (individual factor) still matters as it was rather found that it affected risk-taking behaviour; contrary to expectation, a positive relationship was found between RHCDs comprehension and risk-taking behaviour. As discussed already, habituated action theory of risk perception provides a useful explanation. The habituated action theory states that when one repeatedly engages in high-risk behaviours without the expected undesirable consequences, it decreases the perceived risk that the individual associates with the behaviour (Weyman \& Kelly, 1999). The implication is that drivers familiar with the route/road are more likely to downplay the eminence and severity of the hazard communicated through the sign, hence their risk-taking behaviour. In a nutshell, the current study largely supports RCPM.

\section{Directions for Future Research}

There is an ongoing debate about the relevance of model re-specification (see Karakaya-Ozyer \& Aksu-Dunya, 2018; Tarka, 2018). It has been argued that the use of modification in SEM amounts to exploratory analysis instead of confirmatory analysis or hypothesis testing (Tarka, 2018). This is also noted to produce empirically sound but theoretically meaningless models. As a result, it has been suggested that model re-specification should not be done at all in any study but if it must be done it has to be on a cross-validation sample or in an entirely new study (Karakaya-Ozyer \& Aksu-Dunya, 2018; Tarka, 2018). The revised model will have to be tested in an entirely new study with a different sample. This is also consistent with the current debates in SEM (Karakaya-Ozyer \& AksuDunya, 2018; Tarka, 2018). In short, the revised model represented a proposed re-specified model yet to be tested in an entirely new study.
Though this study is an attempt to test the risk chain process model, there are some methodological considerations that can advance knowledge when incorporated in future studies. The current study is a cross-sectional in nature. Though structural equation modelling provides some evidence of causal inference (Shadish et al, 2002), a longitudinal or a lagged panel design with waves of data collections corresponding to the sequence of the variables in the model can improve the predictive value of the model tested. This is to say that testing risk chain process model through a lagged panel design will enhance its value. It is important to note, however, that such a longitudinal design is impractical within the scope of this study.

Another limitation of the quantitative phase of the study concerns the non-significant relationship between RHCDs comprehension and risk perception on one hand and with decision-making on the other. This is worrying because the intercorrelation matrix showed a significant relationship between RHCDs and decision-making. A corollary is the positive relationship between risk taking behaviour and RHCD comprehension. It was speculated that route familiarity, self-regulatory focus, and other plausible factors may account for this kind of situation. It is recommended that these variables should be incorporated into future studies to enable us to have some certainty about these relationship.

There was no focus on other road users such as private vehicle drivers, motorbike riders, and Uber drivers. This may affect the generalizability of the findings to these other road users. It is, therefore, recommended in future studies should either focus on these other road uses.

Finally, the presentation of the hazardous conditions and road traffic accidents could have also benefited from the use of animations instead of the illustrations developed by the professional visual arts professional. It is believed that the use of animation may enhance the realistic nature of the study. It is, therefore, recommended that future studies investigators should secure the necessary funding to enable them pay for the services of studios to develop such animations. 


\section{Funding}

This study was funded by grant from the New York-based Carnegie Corporation Project "Next Generation of Academics in Africa" that was administered through the University of Ghana, Legon, Accra, Ghana.

\section{Competing Interests}

The author has declared that no competing interests exist.

\section{Acknowledgments}

I acknowledge the financial support provided by Carnegie Corporation and the Carnegie Secretariat based at the University of Ghana, Legon, Accra, Ghana.

\section{REFERENCES}

Akple, M. S., \& Biscoff, R.: Assessment of drivers understanding of road signs in Ghana: A case study along Ho-Afloa-Togo route. International Journal of Business, Management and Social Sciences, 3, 2012, 1, 19-25.

Alvarado, C. J., Smith, M. J., Hoonakker, P. L. T., \& Carayon, P.: Safety climate and its relationship to self-reported injury. Proceedings of Human Factors in Organizational Design and Management-VIII, In M. H. Carayon, P., Robertson, M., Kleiner, B. and Hoonakker, P. L. T. (Eds.), 293-298. Santa Monica, CA: IEA Press, 2005.

Ary, D., Jacobs, L. C., \& Razavieh, A.: Introduction to research in education (6th ed.). Belmont, CA: Wadsworth/Thomson Learning, 2002.

Bazire, M., Tijus, C., Brézillon, P., \& de Lavalette., B. C.: Modeling drivers' decision-making processes from road signs. Joint International Conference on Computing and Decision-making in Civil and Building Engineering, June 14-16, 2006 - Montréal, Canada.

Bellini, E., Benvenuti, S. \& Batistini, C.: Towards a not obtrusive low cost biosystem to assess risk perception in workplace through stress detection. H-Workload 2017: The first international symposium on human mental workload, Dublin Institute of Technology, Dublin, Ireland, June 2830. doi:10.21427/D73920
Cafri, G., Thompson, J.K., Jacobsen, P.B., \& Hillhouse, J.: Investigating the role of appearance-based factors in predicting sunbathing and tanning salon use. Journal of Behavioral Medicine, 32, 2009, 532-544.

Chen, Y. Q., Zhang, S. J., Liu, L. S., \& Hu, J.: Risk perception and propensity in bid/no-bid decision-making of construction projects. Engineering, Construction and Architectural Management, 22, 2015, (1), 2 - 20. http://dx.doi.org/10.1108/ ECAM-01-2013-0011

Christensen, C. M.: The ongoing process of building a theory of disruption. Journal of Product Innovation Management, 23, 2006, 39 55.

Clarke, S.: The relationship between safety climate and safety performance: A Meta-analytic review. Journal of Occupational Health Psychology, Vol. 11, 2006, No. 4, 315-327.

Clarke, S.: An integrative model of safety climate: Linking psychological climate to individual safety outcomes using meta-analysis. Journal of Occupational and Organizational Psychology, 83, 2010, 553-578. http://dx.doi. org/10.1348/096317909X452122

Colquitt, J. A., \& Zapata-Phelan, C. P.: Trends in theory building and theory testing: A five-decade study of the Academy of Management Journal. Academy of Management Journal, 50, 2007, 6, 1281 - 1303.

Cooper, D.: Psychology, risk and safety: Understanding how personality and perception can influence risk taking. Professional Safety, 2003. Nov. Issue, 39-46.

Cortina, J. M., Aguinis, H., \& DeShon, R. P.: Twilight of dawn or of evening? A century of research methods in the Journal of Applied Psychology. Journal of Applied Psychology, 102, 2017, 3, 274-290. doi: http://dx.doi.org/10.1037/ apl0000163

Diamant, I.: DDM (Driving Decision Making): Decision making pattern in graphic driving situations: Relation to personality factors and driving attitudes. International Conference on Traffic and Transport Psychology (ICTTP), Berne, Switzerland, 2000. 
Elvik, R.: Towards a general theory of the relationship between exposure and risk. TØI Report 1316/2014, Institute of Transport Economics, 2014.

Hakkert, A. S., \& Braimaister, L.: The uses of exposure and risk in road safety studies. SWOV Publication \# R-2002-12, SWOV Institute for Road Safety Research, The Netherlands, 2002.

Haque, M., Chin, H. C., \& Lim, B. C.: Effects of impulsive sensation seeking, aggression and risk-taking behaviours on the vulnerability of motorcycles. Asian Transport Studies, 1, 2010, 2, $165-180$.

Hirschi, T.: Causes of delinquency. Berkeley, CA: University of California Press, 1969.

Hofmann, D. A., Burke, M. J., \& Zohar, D.: 100 years of occupational safety research: From basic protections and work analysis to a multilevel view of workplace safety and risk. Journal of Applied Psychology. 2017. Advance online publication. http://dx.doi.org/10.1037/apl0000114

Karakaya-Ozyer, K., \& Aksu-Dunya, B.: A review of structural eqution modelling applications in Turkish educational science literature, 2010 - 2015. International Journal of Research in Education and Science, 4, 2018, 1, 279 - 291. DOI:10.21890/ijres.383177

Makinde, O. O., \& Oluwasegunfunmi, V.: Comprehension of traffic control devices amongst urban drivers: A study of Ado-Ekiti, Ekiti State, Nigeria. European Journal of Engineering and Technology, 2, 2014, 1, 9 - 19.

Martin, L. F.: Cultural differences in risk perception: An examination of USA and Ghanaian perception of risk communication. (Unpublished Master's Thesis). Virginia Polytechnic Institute and State University, Blacksburg,VA, U. S.A. 2003.

McGregor, S. L. T.: Reconceptualizing risk perception: Perceiving majority world citizens at risk from 'Northern' consumption. International Journal of Consumer Studies, 30, 2006, 3, 235246.

Medina, A. L., Lee, S. E., Wierwille, W. W., \& Hanowski, R. J.: Relationship between infrastructure, driver error, and critical incidents. In
Proceeding of the Human Factors and Ergonomic Society 48th Annual Meeting, 2075 - 2080. 2004.

Miner, J. B.: Industrial-Organizational Psychology (International Edition). New York, NY: McGraw-Hill Companies, Inc. 2002.

Ministry of Roads and Transport. Ghana Highway Code. Accra, Ghana: Author. 1974.

National Road Safety Commission. 2010 Annual Report. Accra, Ghana: Author. 2010.

Neal, A., \& Griffin, M. A.: Safety climate and safety behaviour. Australian Journal of Management, 2002. Vol. 27, Special Issue.

Neal, A., \& Griffin, M. A.: A Study of the lagged relationships among safety climate, safety motivation, safety behavior, and accidents at the individual and group levels. Journal of Applied Psychology, 91, 2006, 4, 946 - 953. DOI: 10.1037/0021-9010.91.4.946

Neal, A., Griffin, M. A., \& Hart, P. M.: The impact of organizational climate on safety climate and individual behavior. Safety Science, 34, 2000, 99-109.

Oppong, S.: Health \& safety: Theory and practice in the oil and gas sector. Saarbrücken, Germany: VDM Publishing House Ltd. 2011.

Oppong, S.: Risk chain process model: Linking risk perception to occupational accidents. Sigurnost (Safety), 57, 2015, 1, 25 - 34.

Raouf, A.: Theory of accident causes. In encyclopedia of occupational health and safety (4th ed.). Vol. 2. Geneva: International Labour Office, pp. 56.1 - 56.42. 1998.

Razzak, A., \& Hasan, T.: Motorist understanding of traffic signs: A study in Dhaka City. Journal of Civil Engineering, 38, 2010, 1, 17-29.

Salas, E., Kozlowski, S. W. J., \& Chen, G.: A century of progress in industrial and organizational psychology: Discoveries and the next century. Journal of Applied Psychology, 102, 2017, 3, 589-598. http://dx.doi.org/10.1037/apl0000206

Sandu, C.: The influence of road signs on driver's performance. International Journal of Traffic and Transportation Psychology, 1, 2013, $1,35-41$. 
Sheeran, P., Harries, P.R.,\& Epton, T.: Does heightening risk appraisals change people's intentions and behavior? A meta-analysis of experimental studies. Psychological Bulletin, 2013. doi: 10.1037/a0033065

Tarka, P.: An overview of structural equation modelling: Its beginnings, historical development, usefulness and controversies in the social science. Quality \& Quantity, 52, 2018, 313 - 354. DOI: 10.1007/s11135-017-0469-8

Thepaksorn, P., Siriwong, W., Neitzel, R. L., Somrongthong, R., \& Techasrivichien, T.: Relationship between Noise-Related Risk Perception, Knowledge, and the Use of Hearing Protection Devices among Para rubber Wood Sawmill Workers. Safety and Health at Work. 2017. doi: 10.1016/j.shaw.2017.06.002.

Wilde, G.J.S.: Target risk: Dealing with the danger of death, disease and damage in everyday decisions. Toronto, Canada: PDE Publications. 1994.

Wolfe, A. C.: The concept of exposure to the risk of a road traffic accident and an overview of exposure data collection methods. Accident Analysis \& Prevention, 14, 1982, 5, 337-340.

Zhao, X., Lynch, J. G., \& Chen, Q.: Reconsidering Baron and Kenny: Myths and truths about mediation analysis. Journal of Consumer Research, 37, 2010, 2, $197-206$.

Zohar, D.: A group-level of model of safety climate: Testing the effect of group climate on micro-accidents in manufacturing jobs. Journal of Applied Psychology, 85, 2000, 4, 487 - 596.

Zohar, D.: Thirty years of safety climate research: Reflections and future directions. Accident Analysis and Prevention, 42, 2010, 5, 1517 1522. Doi:10.1016/j.aap.2009.12.019. 


\section{OD PERCEPCIJE RIZIKA DO NESREĆE: EMPIRIJSKI TEST PROCESNOG MODELA LANCA RIZIKA}

SAŽETAK: Svrha ove studije je istražiti utjecaj razumijevanja komunikacijskih dizajna opasnosti na cestama i sigurnosne klime na percepciju rizika, kao i utjecaj potonjeg na prometne nesreće među vozačima komercijalnih vozila u Gani. Dvjesto dvadeset i šest (226) vozača komercijalnih vozila sudjelovalo je u ovoj studiji. Upitnici su podijeljeni vozačima koji su iz grada Akre vozili u devet (9) drugih regija Gane kako bi se poboljšala vanjska valjanost nalaza istraživanja. Analiza staze provedena je korištenjem strukturnog modeliranja jednadžbi na dobivenim podacima. Rezultati SEM-a ili analize staza pokazali su da su svi hipotetski odnosi značajni osim tri. Neznačajni su obuhvaćali staze od razumijevanja RHCD-a do percepcije rizika, odnosno donošenja odluka vozača, kao i put od donošenja odluka vozača do rizičnog ponašanja. Model je pokazao je da predloženi model studije, koji uglavnom proizlazi iz modela procesa lanca rizika, ima empirijsku potporu. Posljedice su da percepcija rizika utječe na ponašanje $i$ odlučivanje u procesu preuzimanja rizika, dok potonje utječe na izloženost riziku. Uz to, sigurnosna klima utječe na percepciju rizika, rizično ponašanje i prometne nesreće. Slično tome, rizično ponašanje utječe na izloženost riziku, dok izloženost riziku utječe na sudjelovanje u cestovnom prometu. O tim se implikacijama razgovaralo u svjetlu postojeće teorije i postojeće empirijske literature.

Ključne riječi: procesni model lanca rizika, percepcija rizika, prometna psihologija, psihologija sigurnosti 